\title{
Reografia
} Malavsian Tournal of Society and Space

\section{A socio-economic transformation of the ECER-development programmes in enhancing the well-being of the people}

\author{
Abdul Rahman Abdul Latip, Norfatiha Othman \\ Department of Policy Studies, Faculty of Business, Economic, and Social Development, \\ Universiti Malaysia Terengganu
}

Correspondence: Abdul Rahman Abdul Latip (email: rahmanlatip@umt.edu.my)

Received: 08 January 2021; Accepted: 19 August 2021; Published: 27 August 2021

\begin{abstract}
Just and sustainable socio-economic development is an important indicator in achieving Sustainable Development Goals (SDG). In 2007, the states in the east coast of Peninsular Malaysia were among the states with the highest poverty rate in Malaysia. East Coast Economic Region (ECER) that has been established in 2008 is an economic development region based on the east coast of Peninsular Malaysia, covers Kelantan, Terengganu, Pahang and the district of Mersing in Johor. The ECER Master Plan, approved by the Government in 2008, was formulated as a basis to guide the development of ECER until 2025 to reduce regional socio-economic disparities, eradicating poverty, creating employment opportunities and improving the standard of living for the local populace. This study aims to analyse the socio-economic transformation brings by ECER into this region in the aspects of job creation, investment, and entrepreneurship opportunities. The study uses the qualitative approach (in-depth interviews) with 10 key informants including direct observation, as well as library research. The informants comprised of five informants from the policy making level, and the remaining five informants from the implementation level. NVivo software used to analyse the qualitative data. The finding of this study finds positive transformations of the ECER development programmes towards the region in terms of investment, job creation, and entrepreneurship opportunities. It is hope that ECER will continue to facilitate the socio-economic transformation of this region towards becoming a developed region by 2025 .
\end{abstract}

Keywords: Development programmes, East Coast Economic Region (ECER), regional development, socio-economic transformation

\section{Introduction}

According to World Bank (2021), Malaysia has successfully reduced hard-core poverty and promoted shared prosperity in order to achieve a high-income and developed country status. However, income inequality in Malaysia remains high compared to other countries in East Asian, 
contributing to widespread perceptions of the poor people particularly in rural areas being left behind. Hutchinson (2017) found that Malaysia regional policy has evolved in tackling this issue. Instead of exclusively focus on rural development, the government give attention on the relationship between location and economic activity. All regions are encouraged to identify and strengthen their comparative advantage. Regional economic development will help to improve the socio-economic status of less developed states in Malaysia.

Through the tenth goal of Sustainable Development Goals (SDGs), which is sustainable development, it calls for reducing inequalities in income as well as those based on age, sex, disability, race, ethnicity, origin, religion or economic or another status within a country (UNDP, 2018). This goal describes the vital objective of development, which is to reduce inequality, improve social well-being and close the gap between develop and undeveloped states and regions through various development programmes and projects.

In the Ninth Malaysia Plan (2006-2010), the main government was concerned on the regional development imbalances. Through the third phase of the Ninth Malaysia Plan, the government aimed at constructively and productively addressing the issue of socio-economic disparities between states and regions in Malaysia. There was an increasing allocation for the development of the rural areas as a strategy to close the gap between rural and urban areas as well as between the less developed and more developed regions. Eradication of the most povertystricken regions and overall poverty reduction became the key priorities. Throughout the Ninth Malaysia Plan, the government started to concern about evaluating the assessment of impacts and effectiveness of the past policies and programmes (Ngah, 2012).

Following the government aspiration, a total of five regional economic corridors were established during the Ninth Malaysian Plan. They comprised Iskandar Development Region (IDR), Northern Corridor Economic Region (NCER), East Coast Economic Region (ECER), Sabah Development Corridor (SDC), and Sarawak Corridor of Renewable Energy (SCORE). ECER involves the states in the east coast of Peninsular Malaysia consisting of Kelantan, Pahang, Terengganu, and Johor (district of Mersing). Physically, ECER covers more than half of the Peninsular Malaysia (51\%) with over 66,000 square kilometres of total area. The vision of ECER is to achieve the status of a developed region by 2020 (ECERDC, 2009).

Under the East Coast Economic Region Development Council Act (Act 688), a statutory body namely East Coast Economic Region Development Council (ECERDC was established to drive the various development programmes planned to be implemented within this region. ECERDC as the responsible body plays an important role in producing a proper direction, suitable policies and dynamic strategies related to the development of this region.

ECER Master Plan approved by the government in 2008 became the blueprint to guide the development within ECER until 2020. The high impact programmes and projects were identified to eliminate poverty, reduce the socio-economic disparities, and increase the income and wealth distribution in a sustainable manner. For this purpose, an allocation of RM6.6 billion has been approved by the federal government under the Ninth, Tenth and Eleventh Malaysia Plans to implement a total of 111 impactful infrastructure, poverty eradication as well as human capital development programmes and projects (ECERDC, 2009).

Since the establishment of ECER in 2008, there were many high-impact projects and programmes implemented in transforming the socio-economic of the people in the east coast states of Peninsular Malaysia. These projects and programmes were divided according to five key drivers namely tourism, oil, gas and petrochemicals, manufacturing, agribusiness and human capital development. ECERDC adopted a multi-prong approach in achieving a sustainable socio- 
economic development. It benefits all segments of the local community in the region. There were several human capital development programmes, each targeting the specific needs of the local population in ECER. It is to safeguard the right of everybody to experience the development that later will decrease socio-economic inequalities in the region. These people economy programmes were aimed at transforming the lives of the target groups especially the low-income households, women, youths and the Orang Asli.

After almost a decade, there is a need to assess the transformation brought by ECER into this region particularly in people economy. There was a huge investment made to this region but the distribution of jobs was still not significant (Abdul Latip, Othman \& Md Yusoff, 2020). The 10 years period from 2008 until 2017 surely gave a huge impact to the socio-economic growth of this region. To date, studies on regional development programmes particularly on regional economic corridors in Malaysia were mainly focused on the Iskandar Development Region. For instance, Mohamed Osman, Bachok, and Rabe (2015) in their study analyzed the local people's perceived socio-economic impacts of Iskandar Malaysia development and their study was limited to the three main socio-economic namely the age, education level, and household's monthly income.

Hence, this study attempts to assess the transformations brought by various ECER development programmes and projects in improving the socio-economic status of the states of Kelantan, Terengganu and Pahang for the period of 10 years since its establishment in 2008 until 2017.

\section{Literature review}

Impact can be described as a longer-term result produced by a programme, project or policy. It may include intended and unintended results, direct and indirect, and positive and negative impacts. The Organisation for Economic Co-operation and Development (OECD) (1999) defines impact evaluation as an analytical assessment on results of any public policies, organisations or programs focusing on the reliability of findings and usefulness inputs for future policy design.

Recently, there is an increasing concern by the government and stakeholders on the need for impact evaluation in public policies. It should feature the decision-making process of social policy, which is vital to justify any funding using the public money to ensure that the programme or project fulfils the local community needs. There are many countries in the world that embraced the practice of impacts evaluation as an important element of good public sector management. Rubio \& Subbarao (2001) in their social protection project funded by World Bank in 1999 indicated that only $20 \%$ of the samples had a well-developed evaluation plan, while just half of them possessed an information base suitable for assessing impact evaluation. Most of the samples have incomplete information or do not have any plan to practice an impact evaluation study.

Apart from that, outputs from impact evaluation can be the best inputs for government to improve their performance in serving people particularly in the aspects of quality and target in delivering maximum benefits through various development programmes and projects. This has been highly agreed by evaluation specialists whereby they believe that the practices of monitoring and evaluation systems are vital due to their inherent merits (Mackay, 2006: 1). If the assessments of impact do not exist, it becomes difficult for the government to make any evidence-based decisions as the needed information is not available. The findings from impact evaluation help the 
government to become aware of the effects of implemented policy towards the public in the region. It also reflects the government's efforts in solving society issues.

Yusoff, Mulok, Md Kamdari and Abdullah (2009) in their study indicated that the development of ECER was formulated with a special attention given on the efforts to reduce the level of poverty and improve the standard of living among the groups of low and middle income in the east coast region of Peninsular Malaysia. There are several approaches taken by the government to increase the income, widen the employment opportunities, and develop entrepreneurship through the small and medium industries.

Another study implied the significant and strong linkages between development programme and socio-economic transformation in many circumstances. The empirical finding showed plausible impacts of development programme in uplifting socio-economic including the creation of jobs, higher incomes for participants, linkages from farming to the rest of the rural economy and reduced prices of food (Irz, Lin, Thirtle \& Wiggins, 2001).

Gennaioli et al. (2013) in their study suggested that regional education is a critical determinant of regional development. Through educated workers and entrepreneurs, the socioeconomic of a region can be improved. The various regional development programmes have helped in reducing poverty situations in the less developed states in Malaysia. By using relevant indexes to trace the changes in poverty incidence, extent and severity, such programmes have increased the economic performance in the states of Kelantan, Terengganu and Pahang (Zaleha \& Asfari, 2013).

Mohamed Osman et al. (2015) in their study on the local resident's perception on socioeconomic impact of Iskandar Malaysia found the positive impact of various development programmes implemented in this region. There are increasing in committed investment, job creation and employment opportunities significantly, meanwhile these programmes also reduces poverty and crime rate issues across the region. Besides that, the young respondents and higher income respondents are perceived socio-economic impacts of Iskandar Malaysia more positively. Apart from that, educated background respondents are agreed that the development programmes implemented have affected environment in the area of study.

Moreover, an evaluation study has been conducted on the impact of public investment programmes towards the regional socio-economic development in Russia. The finding suggested positive impact of the programmes in reducing the unemployment issue and improving the export activity (Limonov \& Nesena, 2019). Latest, a study by Abdul Latip, Othman, and Md Yusoff (2020) on the socio-economic impacts of human capital development programmes on the rural women in ECER states found significant improvement in participant's income after joining the programmes. The participant's live also have transformed especially reducing the poverty issue and improving social well-being and lifestyle. In addition, a study by Haliru, Abu Samah and Ahmad (2019) also found a significant positive relationship between human capital investment and economic wellbeing. The development programme which include training, knowledge, and skills by government have a significant positive relationship to the participant's incomes, life satisfaction and life evaluation.

Beer et al. (2003) explained the broad parameters on what is constituted by regional development. It can be identified as a set of activities aiming at improving the economic wellbeing of an area such as economic development strategy, enterprise, labour, technology initiatives, research, labour market and political lobbying. This was supported by Glasmeier (2000) whereby in the 1960s, approaches to development were focused on redistributing opportunities for wealth creation and enhanced economic well-being. 
The various socio-economic development programmes also have effect on the people well-being. A study by Ülengin, Kabak, Önsel and Parker (2011) found a strong connection between economic growth and social well-being. In achieving a sustainable regional development, improvement in social aspect will support economic growth. Conversely, a slow social well-being can ruin the fasteconomic growth of a region (World Bank, 2000).

As discussed by Nik Muhammad et al. (2011), the socio-economic development programmes will have a direct effect in increasing total wealth which can automatically improve well-being of people in a region. In achieving sustainable development, human development factor must be considered. The social aspect of communities would also improve the quality of life among people (Hassan et al., 2013). Other than economic, the indicators such as socio-economic development and well-being of the local population should be at the top priority in measuring a balanced and sustainable regional development.

\section{Method and study area}

This study focusing the socio-economic transformation of ECER states by combining both primary and secondary data in achieving the objective. For the primary data, this study used qualitative method which utilized in-depth interview with 10 key informants. In-depth interviews focused on underlying the socio-economic transformations of ECER development programmes. It was held with informants involved in the decision making and implementation level of development programmes within ECER regions.

This study used non-probability samples for selecting the population. The sample was not intended to be statistically representative in which the chances of selection for each element is unknown but, instead, the characteristics of the population were used as the basis of selection. Purposive sampling was used to choose samples from the population. For this approach, the criteria to select the participants, settings or other sampling units are based on purposive sampling (Mason, 2002; Patton, 2002). The chosen sample units possessed the particular features or characteristics needed by the researcher, which enabled a detailed understanding and exploration of the central themes and puzzles intended to be studied.

Semi-structured interviews were used in this study, where questions are predetermined, but the order and the wording can be modified where questions can be omitted or added during the interview (Mohd Tobi, 2016). The key informants were among the professionals involved in the decision making and implementation level. It was essential to gain their expert view on the transformation brought by ECER development programmes in the region. The questions were adapted from Powell, Steele \& Douglah (1996). There were 14 questions involved during the face to face interview with the policy makers and implementers. Among the questions asked to assess the transformations brought by ECER development programmes were the overall impact of development program on local community of ECER and the target group, the local community's satisfaction with what they gain from the development programmes, the social, economic, environmental impacts (positive and negative) on people, communities, and environment, and how efficiently are clientele and agency resources being used.

The informants comprised of five informants from the policy making level, and the remaining five informants from the implementation level. At the policy making level, it involved the Director of Outcome Evaluation at the Implementation Coordination Unit (ICU), Director of 
Regional Development Section from Economic Planning Unit (EPU) of the Prime Minister Department, and three officers from the EPU in the states of Terengganu, Pahang, and Kelantan. As for the implementation level, this study involved the directors and officers from each ECER states.

The interviews and discussions translated and transcribed. Each interview session took between 45 minutes to one and a half hours the researcher recorded all the conversations. In this study, the thematic analysis was used to organise the qualitative data. The data were organised in a systematic way by coding and coordinating the data into themes. In systematically evaluating the transcriptions, semantic method was conducted to analyse the content of the statements from the key informants. This method is useful to scrutinise, interpret and understand the issue that examined in a study. In the coding process, the researcher did not only focus on the transcribed data, but also include the data from official reports, journals, books and field notes from observation. In the end, the themes created could answer the objectives of this study.

\section{Results and discussion}

Socio-economic transformation of development programmes on investment, job creation and entrepreneurship opportunities in ECER

As shown in Table 1, the impact of ECER development programmes were significant to the region. Up to 2016, the total investment made by ECER was RM101 billion, which was RM9 billion away from the targeted investment by 2020. The private investments and human capital development programmes were expected to create about 130,000 job opportunities and produce about 23,000 entrepreneurs, especially among those from the lower-income group (Bottom 40 Group). Most of them were the recipients of livelihood assistance from government. Through the production of 23,000 entrepreneurs, about 28,000 job opportunities for the local people were expected, which potentially improve the living standards and well-being of the local community. The efforts of attracting potential investments by ECERDC were also supported by the human capital development initiatives, which succeeded in transforming more than 61,000 local people, where $97 \%$ of them were from the B40 group (ECERDC, 2017).

Table 1. Impact of ECER Development Programmes on investment, job creation, and job entrepreneurship opportunities.

\begin{tabular}{lll}
\hline & Targeted & Achievement \\
\hline Investment & 110 Billion & 111.6 Billion \\
Job Opportunities & 130,000 & 108,400 \\
Entrepreneurship & No specific Target & 9,660 \\
Opportunities & & \\
\hline
\end{tabular}

Referring to figure 1, the manufacturing sector attracted the highest investment, which amounted to about 53\% of the total investment from 2007 to 2016. As a result, about 52,777 job opportunities were created for local people. The tourism sector, which contributed about $18 \%$ of the total investment, provided 20,237 job opportunities. Besides that, the bio economic sector was identified as another significant sector that contributed $8 \%$ of the total investment and 5,509 job opportunities. Meanwhile, the oil and gas sector brought about $7 \%$ of the total investment, which produced 3,366 job opportunities. 


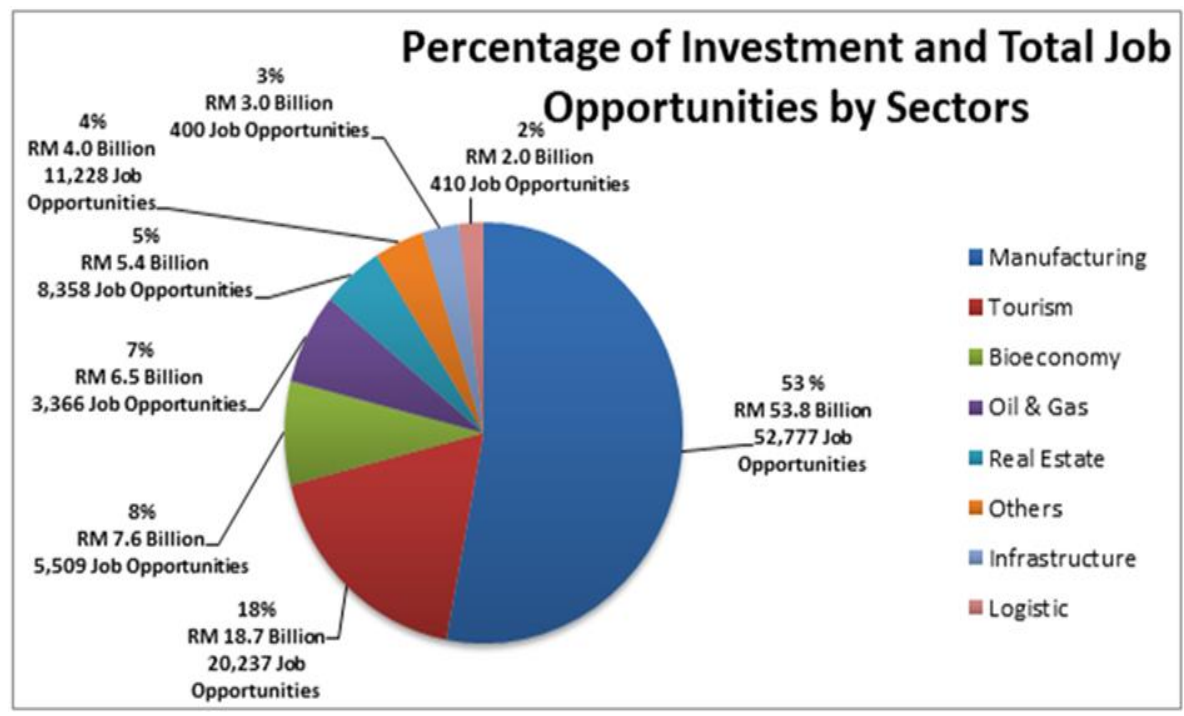

Source: ECERDC (2017)

Figure 1. Percentages of investments and total job opportunities by sectors from 2007 to 2016.

According to figure 2, compared to the public investment of RM7.8 billion in 2017, ECER managed to attract private investments with a return of RM111.6 billion into the region where $50 \%$ of the total investment was realised. It was expected to provide 108,400 job opportunities where 57,800 of these job opportunities were realised for these local people. As for the entrepreneurship industry, ECER managed to create about 9,660 entrepreneurship opportunities up to 2017 (ECERDC, 2018).

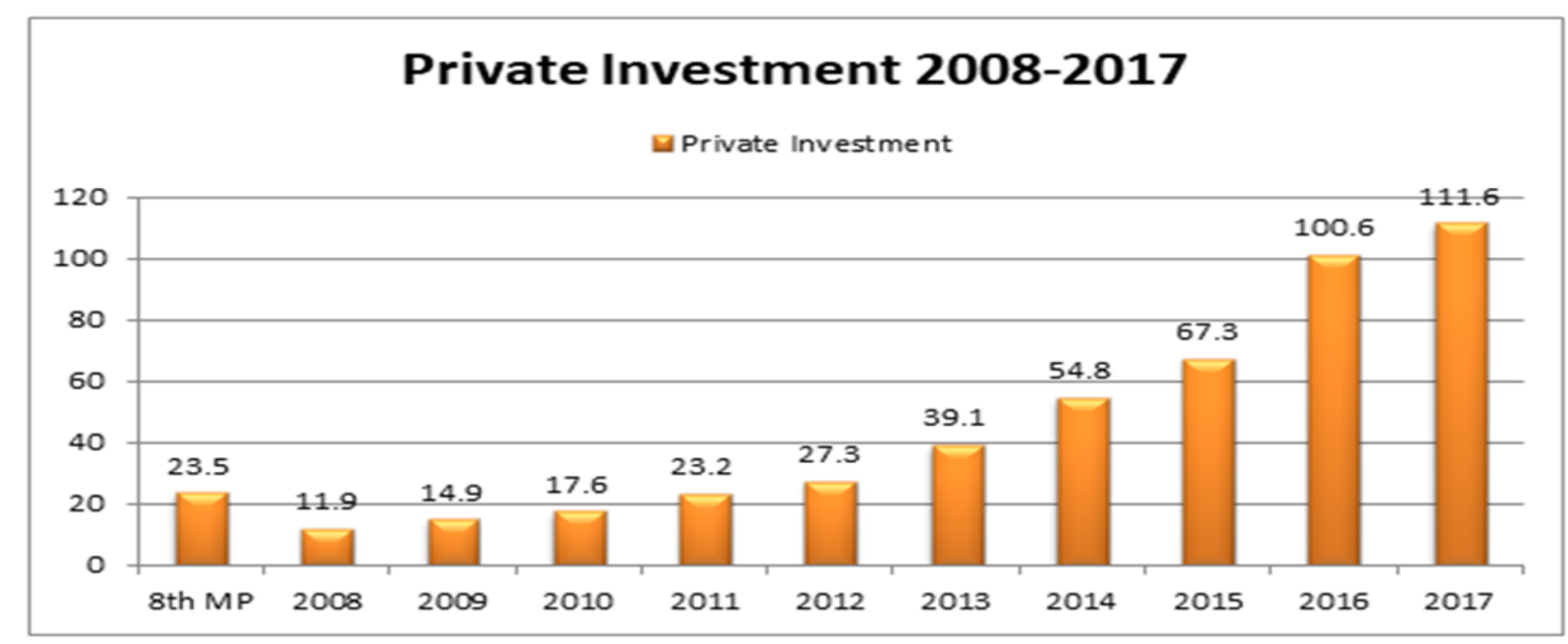

Source: ECERDC (2017)

Figure 2. Private investments from the year 2008-2017.

Overall, the transformation by ECER for this region was found positive through the implementation of three main programmes under the ECERDC. Firstly, the development of infrastructures that involve numerous mega projects across the states of ECER. For instance, the East Coast Rail Link (ECRL) project, which is currently in construction, is expected to boost the 
socio-economic development of the region. The completed infrastructure potentially attracts huge investments into the region. As elaborated by one of the respondents, the creation of numerous job opportunities is expected, which has been encouraging for the people economy in ECER:

"ECER has three main programmes. First, it is about infrastructure. If we look at the areas in ECER, there are many infrastructure projects that currently still in construction and many of them have completed successfully. Latest, we have ECRL, and we hope all of these projects will attract private companies to invest in ECER

...Meanwhile, people in this region can enjoy the facilities provided. In the capital economy, it also depends on the people. For instance, when we attract investors, there are more job opportunities created. We also have vendor and supplier that can provide business to the local community. So now we have infrastructure, investments and people economy. It complements each other...

(Respondent No. 3, Kuala Lumpur)

Back in 2015, the Implementation Coordination Unit (ICU) of the Prime Minister Department conducted a study on the satisfaction of local people in the ECER region towards the implementation of various development programmes. The study revealed that they were generally satisfied with the outcomes of these programmes. In particular, the citizen satisfaction index showed that ECER achieved more than $70 \%$ for most of the indicators in the aspects of economic, social, physical and environment, and delivery and services, which were identified as important indicators of successful implementation of development programmes across the states of Kelantan, Terengganu, and Pahang as well as the district of Mersing (Johor). The overall transformation was found clear and positive.

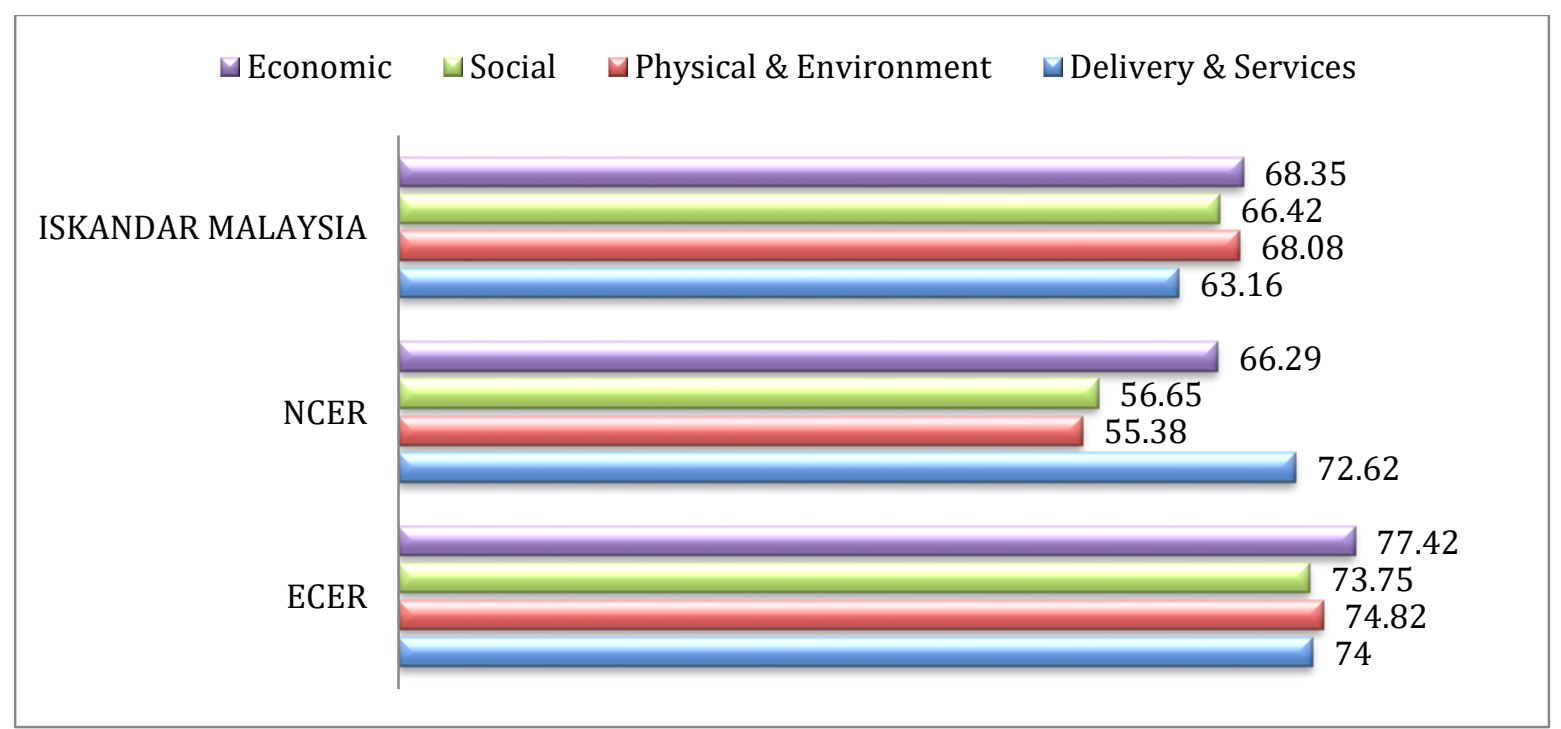

Source: Implementation Coordination Unit (2017)

Figure 3. Citizen satisfaction index by corridors

As stated by the one of the respondents of Implementation Coordination Unit (ICU) at Prime Minister Department, ECER managed to bring a clear socio-economic transformation into 
the region. Based on the findings from Citizen Satisfaction Index, the various development programmes implemented by ECER have improved the socio-economic status of local community, particularly in rural areas. These programmes also reach the targeted groups; low-income households, women, youths, Orang Asli. ECER has brought positive changes to their life.

...Yes, there is a clear transformation in term of socio-economic growth in the east coast region brings by ECER. In fact, when we carried out the study to the targeted people in this region, they were agreed that these programmes have contributed to the improvement of their socio-economic. In a way, I would say they could feel and see the changes brought by ECER...

(Respondent No.1, Putrajaya)

Additionally, ECER had managed to establish a wide range of entrepreneurial opportunities that had produced thousands of new entrepreneurs within the region. The implementation of empower and entrepreneur programmes had reduced the dependency on the industrial areas. Hence, training and skills provided had been proven to have created numerous job opportunities and had contributed to the socio-economic impacts of the local community in ECER.

...All this time, the development centred in West Coast of Peninsular Malaysia because they have many industrial areas there, but somehow ECER managed to create a niche that they do not totally depend on industry to develop the rural area. The branding that shows people were satisfied and happy with ECER more than people in the northern economic corridor. They have established the impacts. They managed to bring transformation towards the community in east coast region...

(Respondent No.1, Putrajaya)

All in All, the Outcome and Evaluation Section of ICU considered that the ECER had brought about positive transformations into the region. Furthermore, ECER managed to create impactful development projects and human capital development programmes for the local community in the region. For the last decade until 2017 significant changes were achieved whereby states that had failed to attract foreign companies invested in states that were successfully luring in hundred billions of investment opportunities. The public investment in the region seemed worthy when multiple doors of employment opened up. This in return created new entrepreneurial opportunities for the local community specifically the rural areas. Hence, one of the respondents concluded:

...There are many positive impacts brings by ECER. If we can compare, before the establishment of ECER, there was nothing much in the east coast. We know that they have Petroleum. That's it and so much about Petronas only. Now, they are so many things there. That is what I can see regarding the transformation brings by ECER. If can give a rating, I would root for seven out of ten. It based on my limited exposure. They bring positive transformation, but when we go to micro, we knew what happened... 


\section{Socio-economic transformation in Terengganu}

In Terengganu, various development programmes, such as physical projects, infrastructure projects, and human capital development programmes, contributed positive impact on the socioeconomic status of the local people. As elaborated by one of the respondents in Terengganu, the ECER Terengganu policy on hiring the local people in management-related work and maintenance work was deemed beneficial. It provided job opportunities for the local people and avoided any wastage of available workforce:

...According to ECERDC policy, $100 \%$ of the officers for the management department came from Terengganu or local people. Once a project accomplished, the staff for maintenance works hired among the local people...

(Respondent No. 8, Terengganu)

ECER has proved to be essential for the state government to ensure progressive development in Terengganu. As an organization that receives a huge amount of budget from the federal government, the roles of ECER in this state appear to be highly important. The implementation of high-impact projects by ECER has transformed the state of Terengganu to a higher level, which has attracted many foreign and domestic investors into the state. As for the aspect of social development, programmes such as empower ECER was said to have complemented the currently implemented human capital programmes under the state government. According to another informant from the EPU Terengganu:

"If we look on the ECER contribution to this state, ECER supports and assists what have been implemented by the state government. In term of infrastructure, we have a budget constraint on spending on infrastructure. ECER not completing the infrastructure that we have planned but ECER has contributed to total new infrastructure development. On the other part, human capital development programmes such as empower programme are very helpful and complement what has been done by government state."

(Respondent No. 4, Terengganu)

\section{Socio-economic transformation in Pahang}

Meanwhile, the socio-economic transformation by ECER in Pahang appears to be significantly positive. The state also recorded the biggest allocation of investments for various development projects and programmes across the state. The development programmes succeeded to reach the targeted groups, particularly students, youths, housewives, and entrepreneurs, within the state. These projects such as ECRL are highly welcomed in Pahang because such projects boost the economic growth, which allow the states of ECER to be able to rival the other parts of Malaysia. As stated by one of the informants in Pahang:

...Overall, there are many transformations happened. A lot of programmes have been implemented for school students until entrepreneur, transforming them to a better level. You have to understand ECER has been established under the Prime Minister 
Department according to Parliament Act to balance up development in the east coast region and west coast of Peninsular Malaysia...

Another significant transformation by ECER in Pahang is related to investment. It is important to attract many foreign investors and the state of Pahang is the preferred destination to invest on. The ECER initiatives that lead to the development of many physical and infrastructure projects are considered as the key factor that attracts large contribution of private investments into the state. All these attempts are beyond the capacity of the state government. The high impacts of physical and infrastructure projects as well as the people empowerment programmes have improved the socio-economic status, particularly in the rural area. An informant from EPU Pahang revealed the following:

...In term of investment, ECER involved in attracting foreign investors come into this state. So far, the total of investment brought by ECER is about RM102 billion if I am not mistaken. Compared to the capacity that this state government could afford, ECER is very significant to the socio-economic development in Pahang. Most of the projects are high-impact projects. Apart from that, the empowerment programmes are giving many benefits to the local community and entrepreneurs in Pahang. These programmes also improved the income of rural area community...

(Respondent No.5, Pahang)

\section{Socio-economic transformation in Kelantan}

On the other hand, the local people in Kelantan, a state with the highest poverty rate in the east coast region, have experienced improved socio-economic status through the establishment of ECER in the state. The human capital development programmes, such as Entrepreneur ECER, have improved the profitability and productivity of the local products. Some of the companies also successfully penetrate the international market due to the assistance provided by these programmes. Numerous participants of the programmes, such as empower ECER, also recorded success stories of starting their own business after they received intensive training. The Halal Hub in Pasir Mas is 177 ecognized as the halal market centre in this region. One of the informants in Kelantan revealed the following:

...I would say that there is positive transformation brings by ECER to this state especially in human capital development. There also many physical projects implemented for this state. Once the entire project accomplished, ECER could provide so many job opportunities...

(Respondent No. 10, Kelantan)

Since most of the implemented projects remain in progress, it has become rather challenging to determine the impact of the entire development projects under the ECER. The long-term projects may take up to about five to 10 years before the government is able to observe the socio-economic impact of these projects. Nevertheless, quick win projects, such as empower ECER, Entrepreneur ECER, and Suri@Home programmes, yield direct impact on the participants. These planned initiatives under the ECER are highly effective for the sustainability of the programmes. The 
handholding process is also a powerful tool to avoid any wastage of resources. The above attributes are considered as one of the uniqueness of ECERDC since the participants are monitored for as long as six months after the completion of the course. At the same time, the ECERDC officer continues to guide the participants to be successful entrepreneurs or to improve their job performance. In view of the above, one of the informants revealed the following:

...Based on my observation, some of the development programmes especially on people economy seems good. For example, we can see the direct impacts of Suri@Home programme towards housewife. Based on the report received, it looks effective in helping the housewife at home. At least they have something to do that can increase their household incomes. It is because this programme has the element of handholding. From the beginning, once they joint this program, ECER gave them training, searching for Anchor Company, and those who need certification, they provide training to ensure they can get the certification. In this case, it seems a very good initiative...

(Respondent No 2, Putrajaya)

\section{Discussion}

Figure 4 described the outcomes and impact evaluation of various ECER development programmes implemented in Kelantan, Terengganu, and Pahang. The objective of this study was to assess the transformation by ECER for the development of this region from 2008 to 2017 in terms of investment, job creation, and entrepreneurship opportunities. ECER intended to address the low socio-economic status of the local community. Numerous inputs were provided to tackle this issue. The infrastructures, staff and appointed service providers proved the investment made by ECER. Hence, these inputs had resulted in an array of education and training programmes for the targeted groups. Similarly, the activities brought about immediate outcomes. It consisted of what they had learned or produced from the activities. Therefore, in the long run, it would result in greater achievements in terms of the employment rates and income. In the end, the implementation of human capital development programmes had achieved the community goal, which was to enhance the people well-being.

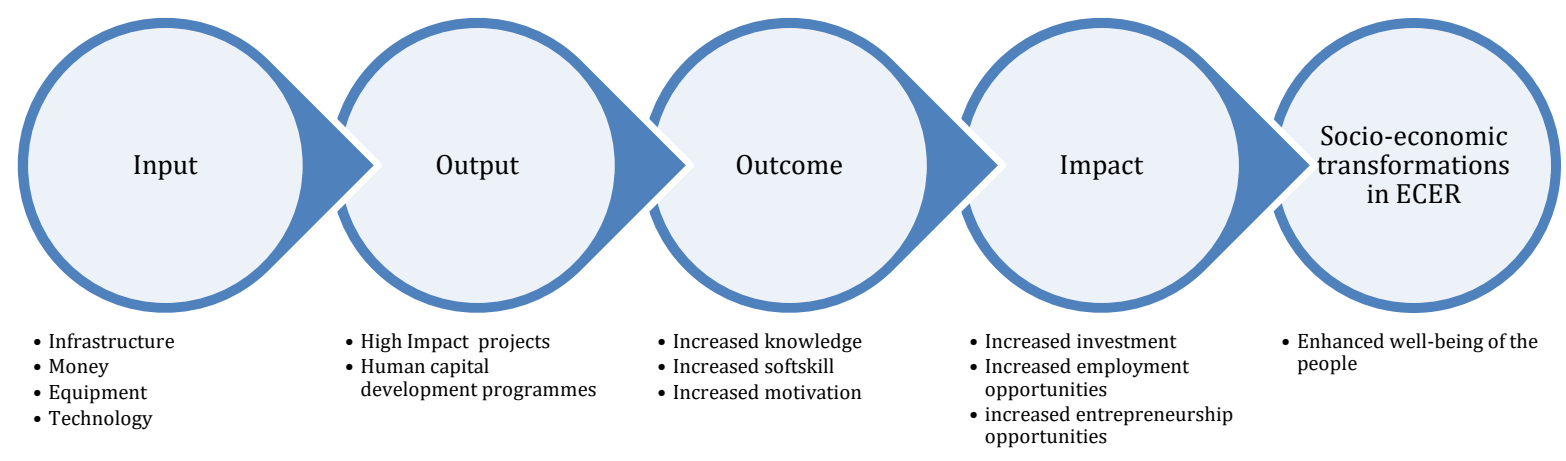

Figure 4. Outcomes and impact evaluation of ECER Development Programmes. 
Based on the study by Haliru et al. (2019) which indicated positive relationship between human capital investment and economic wellbeing, this entrepreneurship programme by ECER also enhancing the wellbeing of the people in this region. In short, the investment on new ideas and knowledge delivers impactful return to the regional development. The increasing number of entrepreneurs across the region reflects the active participation of local people in the development process. In other words, it can be a significant push factor for the socio-economic growth of the region along with the implementation of various development programmes.

It consistent with the finding of the latest impact evaluation study by Limonov and Nesena (2019), which found positive impact of the development programmes on the job opportunities and export activity in the region. Finding from this study found the development programmes by ECER not only increasing the job opportunities and investment in the region, but these programmes have created a social equity among the local community through the entrepreneurship activities. The participants, particularly women have been given access to knowledge and training, opportunity to work, and participate in the socio-economic development process.

\section{Conclusion}

This paper has highlighted the socio-economic changes brought by various ECER development programmes and projects in the east coast states of Peninsular Malaysia in terms of investment, job creation, and entrepreneurship opportunities. Conclusively, the socio-economic transformation of ECER in the development of the region for the past ten years is generally positive and satisfactory.

The government could use the findings from this study to improve the framework that is currently used by the Implementation and Coordination Unit (ICU) of the Prime Minister Department in monitoring and evaluation of government projects. Prior to this, the government does not apply any impact assessment as the evaluation process is implemented only up to the point where the outcomes are obtained. The obtained findings of this study can be used in their framework to improve the implemented evaluation assessment. Essentially, this study provided empirical evidence on the contribution of government investment in physical and human capital. In other words, this study proved the importance of complementing both capital economy and people economy to achieve a sustainable development region.

Despite of the positive transformations happened since its establishment in 2008, ECER should focus on continuing the effort to facilitate this region towards becoming a developed region. Apparently, as for the physical and infrastructure aspects, there are many on-going development projects that still waiting to benefit the people and it is important for ECER in complementing both capital economy and people economy to achieve a sustainable development region.

\section{References}

Abdul Latip, A. R., Othman, N., \& Md Yusoff, O. (2020). Socio-economic impacts of ECER human capital development programmes in empowering the rural women of Malaysia. International Journal of Business and Society, 21(1), 387-398.

Beer, A., Haughton, G., \& Maude, A. (2003) Developing Locally: An International Comparison of Local and Regional Economic Development. Bristol: Policy Press. 
East Coast Economic Region Development Council. (2009). East Coast Economic Region Development Council Annual Report: 2008. Retrieved from https://www.ecerdc.com.my/en/media-room/publications/

East Coast Economic Region Development Council. (2017). East Coast Economic Region Development Council Annual Report: 2016. Retrieved from https://www.ecerdc.com.my/ en/media-room/publications/

East Coast Economic Region Development Council. (2018). East Coast Economic Region Development Council Annual Report: 2017. Retrieved from https://www.ecerdc.com.my/ en/media-room/publications/

Gennaioli, N., Laporta, R., López-de-Silanes, F., \& Schleifer, A., (2011). Human capital and regional development, Economics Working Papers 1286, Department of Economics and Business, Universitat Pompeu Fabra,

Glasmeier, A. (2000). Economic geography in practice: local economic development policy. In: G.L. Clark, M. Feldman and M. Gertler (eds). The Oxford Handbook of Economic Geography. Oxford: Oxford University Press.

Haliru, I., Abu Samah, A., \& Ahmad, N. (2019). Relationship between Human Capital Investment and Economic Wellbeing: A Case Study in Business Apprenticeship Training Centers (BATCs), Kaduna, Nigeria. Pertanika Journal of Social Science \& Humanities, 27(S1), 143-155.

Hassan, N., Mohd Jaafar, N. I., Raja Ariffin, R. N., Abu Samah, A., \& Mohd Jaafar, N. (2013). Perceptions on quality of life in Malaysia: The urban-rural divide. Planning Malaysia Journal, 11(3). doi: 10.21837/pmjournal.v11.i3.106

Hutchinson, F. (2017). Evolving Paradigms in Malaysia's Regional Development Policy. Journal of Southeast Asian Economies, 34(3), 462-487.

Irz, X., Lin, L., Thirtle, C., \& Wiggins, S. (2001). Agricultural productivity growth and poverty alleviation. Development Policy Review, 19(4), 449-466. doi:10.1111/1467-7679.00144

Limonov, I., \& Nesena, M. (2019). Evaluation of the impact of public investment programs on social and economic performance of territories. Voprosy Ekonomiki, (1), 109-123. doi: 10.32609/0042-8736-2019-1-109-123

Mackay, K. (2006). Evaluation capacity development institutionalisation of monitoring and evaluation systems to improve public sector management. ECD Working Paper Series no 15, January 2006. Independent Evaluation Group \& the Thematic Group for Poverty Analysis, Monitoring and Impact Evaluation: The World Bank.

Mason, J. (2002). Qualitative Researching. 2nd edition. London: Sage.

Mohamed Osman, M., Bachok, S., \& Rabe, N. S. (2015). Local residents' perception on socioeconomic impact of Iskandar Malaysia: an example of urban regeneration program in Malaysia. Procedia - Social And Behavioral Sciences, 170, 58-69.

Ngah, I. (2012). Challenges of regional development in Malaysia in the globalization context. International Conference on Regional Development, Vulnerability, Resilience, and Sustainability, Semarang 9-10 November 2011. Retrieved from https://www.researchgate. net/publication/283078879_Challenges_of_Regional_Development_in_Malaysia_in_the_ Globalization_Context

Nik Muhammad, N. M., Md Isa, F., Othman, S. N., \& Che Yaacob, H. (2011). Regional economic development: Rethinking the region. Journal of Information Technology and Economic Development, 2(1), 74-82. 
Organization for Economic Cooperation and Development (OECD). (1999). Improving evaluation practices: best practice guidelines for evaluation and background paper. OECD Public Management Service PUMA/PAC(99) 1.

Patton, M. Q. (2002). Qualitative research and evaluation methods (3rd ed.). Thousand Oaks, CA: Sage.

Powell, E., Steele, S., \& Douglah, M. (1996). Planning a Program Evaluation. Retrieved from http://learningstore.uwex.edu/assets/pdfs/G3658-1.PDF

Rubio, G., and Subbarao, K. (2001). Impact evaluation in bank projects: A comparison of fiscal 1998 and 1999. Mimeo, Poverty Reduction and Economic Management Network, World Bank

Mohd Tobi, S. U. (2016). Qualitative Research, Interview Analysis \& NVIVO 11 Exploration (1st ed.). Kuala Lumpur, Malaysia: ARAS Publisher.

Ülengin, F., Kabak, Ö., Önsel, S., Aktas, E., \& Parker, B. R. (2011). The competitiveness of nations and implications for human development. Socio-Economic Planning Sciences, 45(1), 16-27.

UNDP. (2018). Sustainable Development Goals. Retrieved from https://www.undp.org/ content/undp/en/home/sustainable-development-goals.html

World Bank (2021). The World Bank in Malaysia. Retrieved 13 August 2021, from https://www.worldbank.org/en/country/malaysia/overview

World Bank (2000). World Development Report: Attacking Poverty. New York: Oxford University Press. Retrieved from https://documents1.worldbank.org/curated/en/230351468332946 759/pdf/226840WDR00PUB0ng0poverty0200002001.pdf

Yusoff, R., Mulok, D., Md Kamdari, N. A., and Abdullah, M. F. (2009). Pembangunan ekonomi wilayah pantai timur: satu konsep teori dan perlaksanaan pembangunan di negeri Kelantan. Retrieved from https://www.researchgate.net/publication/292137351_ Pembangunan_Ekonomi_Wilayah_Pantai_Timur_Satu_Konsep_Teori_dan_Perlaksanaan _Pembangunan_Di_Negeri_Kelantan

Zaleha, M. N., \& Asfari, N. A. (2013). Regional development programmes and poverty reduction in east coast states of Malaysia. Pertanika Journal of Social Sciences \& Humanities, 21(S), 201-210. 